\title{
PRACTICAL APPLICABILITY AND PRELIMINARY RESULTS OF THE BALTIC ENVIRONMENTAL SATELLITE REMOTE SENSING SYSTEM (SATBAŁTYK)
}

\author{
Mirosława Ostrowska ${ }^{a}$ \\ Mirosław Darecki ${ }^{\mathrm{a}}$ \\ Adam Krężel ${ }^{\text {b }}$ \\ Dariusz Ficek ${ }^{c}$ \\ Kazimierz Furmańczyk ${ }^{\mathrm{d}}$ \\ a) Institute of Oceanology Polish Academy of Sciences, Poland \\ b) University of Gdańsk, Institute of Oceanography, Poland \\ c) Pomeranian University in Słupsk, Poland \\ d) University of Szczecin, Poland
}

\begin{abstract}
The SatBałtyk (Satellite Monitoring of the Baltic Sea Environment) project is being realized in Poland by the SatBattyk Scientific Consortium, specifically appointed for this purpose, which associates four scientific institutions: the Institute of Oceanology PAN in Sopot - coordinator of the project, the University of Gdańsk (Institute of Oceanography), the Pomeranian Academy in Stupsk (Institute of Physics) and the University of Szczecin (Institute of Marine Sciences). The project is aiming to prepare a technical infrastructure and set in motion operational procedures for the satellite monitoring of the Baltic Sea ecosystem. The main sources of input data for this system will be the results of systematic observations by metrological and environmental satellites such as TIROS N/NOAA, MSG (currently Meteosat 10), EOS/AQUA and Sentinel -1, 2, 3 (in the future). The system will deliver on a routine basis the variety of structural and functional properties of this sea, based on data provided by relevant satellites and supported by hydro-biological models. Among them: the solar radiation influx to the sea's waters in various spectral intervals, energy balances of the short-and long-wave radiation at the Baltic Sea surface and in the upper layers of the atmosphere over the Baltic, sea surface temperature distribution, dynamic states of the water surface, concentrations of chlorophyll a and other phytoplankton pigments in the Baltic waters, spatial distributions of algal blooms, the occurrence of coastal upwelling events, and the characteristics of primary production of organic matter and photosynthetically released oxygen in the water and many others. The structure of the system and preliminary results will be presented.
\end{abstract}

Keywords: bearing capacity factor, displacement, compression, tension, depth factor

\section{INTRODUCTION}

Highly significant part of the ongoing transformation of the Earth's natural environment worldwide is being played by processes taking place in marine ecosystems. It leads researchers to intensify the studies and monitoring of the state and productivity of different seas and oceans. For many years now, various environment state parameters were measured at sea using traditional in situ methods on board of research vessels. Such traditional methods are costly, not very effective and do not satisfy some of the present-day requirements. Monitoring of the vast expanses of seas and oceans, characterized usually by high temporal variability requires more systematic approach. Development of remote methods to investigate the functioning of marine ecosystems, particularly those based on satellite observations of sea colour, enables the efficient global monitoring of the state of the sea. The paper presents some of the most essential results from SatBałtyk project. Its aim is to develop monitoring system for the Baltic, based mostly on the space born information. 


\section{SHORT HISTORY OF REMOTE SENSING OF THE BALTIC SEA}

The beginnings of the remote sensing of the Baltic Sea by Polish scientists go back to the early 1990s. It was a time when they start to develop on the one hand the modelling of bio-optical phenomena taking place in the sea $[8,13,14,20,22,23,25]$, and on the other hand, remote optical methods for studying the functioning of marine ecosystems, in particular techniques based on satellite observations $[6,7,11,12,15,17,24]$.

In 2001-2005 the Institute of Oceanology PAN, together with the Institute of Oceanography (University of Gdańsk), the Pedagogical (now Pomeranian) Academy of Słupsk, and the Sea Fisheries Institutes of Gdynia, conducted research within the framework of a project commissioned by the Polish Committee for Scientific Research - DESAMBEM (DEvelopment of a SAtellite Method for Baltic Ecosystem Monitoring; project No. PBZ-KBN 56/P04/2001).

That project's objective was to develop scientific principles and methods for utilising remote sensing technology to monitor the Baltic, an enclosed sea with a high level of biological productivity. This cooperation yielded the first version of the DESAMBEM algorithm which enables to make, using remote sensing data, a set of map with spatial distribution of four significant characteristics of the Baltic Sea, namely, photosynthetically active radiation (PAR) at the sea surface, sea surface temperature, surface chlorophyll $a$ concentration and total primary production in the water column $[18,19]$.

It was obvious, that those results should be implemented in the interests of the efficient and systematic monitoring of the state of the Baltic environment and the forecasting of the changes taking place in it. This imposes the duty of conserving the natural environment of the Baltic in accordance with international conventions and legal regulations.

The implementation of the DESAMBEM methods has become possible in early 2010 thanks to EU funding. Thus came into being project No. POIG.01.01.02-22-011/0900 entitled 'The satellite monitoring of the Baltic Sea environment' (acronym SatBałtyk) realized in Poland by the SatBałtyk Scientific Consortium, specifically appointed for this purpose, which associates four scientific institutions: the Institute of Oceanology PAN in Sopot - coordinator, the University of Gdańsk (Institute of Oceanography), the Pomeranian Academy in Słupsk (Institute of Physics) and the University of Szczecin (Institute of Marine Sciences).

The main aim of the SatBałtyk project is to prepare the technical infrastructure and set in motion practical operational procedures for the efficient, routine monitoring of the state of the Baltic environment described at the moment by more than 90 structural and functional characteristics, The expected end result of the project is to set up an operational system for the rapid and efficient determination of these characteristics of the Baltic Sea in the form of maps showing their distribution in this sea. This complex task is being implemented (2010-2015).

\section{THE THEORETICAL BASIS OF OPERATIONAL SYSTEM SATBAETYK}

The use of remote sensing methods in studies of the sea is relatively simple only with respect to the waters of the central oceanic regions. The great majority of substances affecting the colour of the sea in those regions are autogenic, that is, formed by the local ecosystem - photosynthesis by phytoplankton and the metabolism and decay of marine organisms. In consequence, the spectrum of the light emerging from these waters and reaching satellite sensors is correlated with the concentration of phytoplankton and its pigments, principally chlorophyll $a$, the commonest plant pigment.

Most of the algorithms now in common use for characterizing the state and functioning of marine ecosystems on the basis of remote sensing data are thus applicable to these waters: they utilize the correlations of their optical properties with the chlorophyll $a$ concentration in surface waters and the correlation of this concentration with other properties of the aquatic environment (e.g. [1,3-5,9,16,21]). In contrast, the construction of analogous algorithms for the optically complex waters of Baltic Sea basin, is much more complicated Apart from chlorophyll and other products of the local ecosystem, such waters contain many substances entering it from the exterior (from rivers, the land, the atmosphere, the sea bed and shores), which have complex optical properties, not directly correlated with the chlorophyll $a$ concentration [26]. The use of remote sensing techniques to monitor such waters requires the application of different algorithms, purpose-designed for a particular sea region. A serious problem hampering the design and use of these algorithms is also the high variability of atmospheric states, which distort the light spectrum bearing information from the sea to the satellite. Work on the development of suitable algorithms for the Baltic Sea has been going on in Poland for the last 20 years by the teams of researchers from mother institutions of authors of this presentation [27,28]. We now present only the most essential information characterizing the progress of this modelling.

Figure 1 illustrates the simplified general block diagram of main components of the SatBałtyk operations system. This system consists of two independent but coordinating subsystems:

The DESAMBEM Diagnostic System, upon which the entire SatBałtyk operations system is founded, enables current structural and functional parameters of the marine environment to be determined on the basis of the relevant calculations, for which the input data are the results of current remote sensing data acquisition.

The BALTFOS Forecasting System based on a packet of prognostic hydrodynamic and ecological models.

Both, DESAMBEM and BALTFOS contain sets of algorithms (in view of the sequence of the calculations to be carried out and their complexity, in Fig. 1 some blocks of subalgorithms were distinguished) enabling diagnose current or forecasted the future sea states on the basis of appropriate input data, the sources of which are principally satellite 


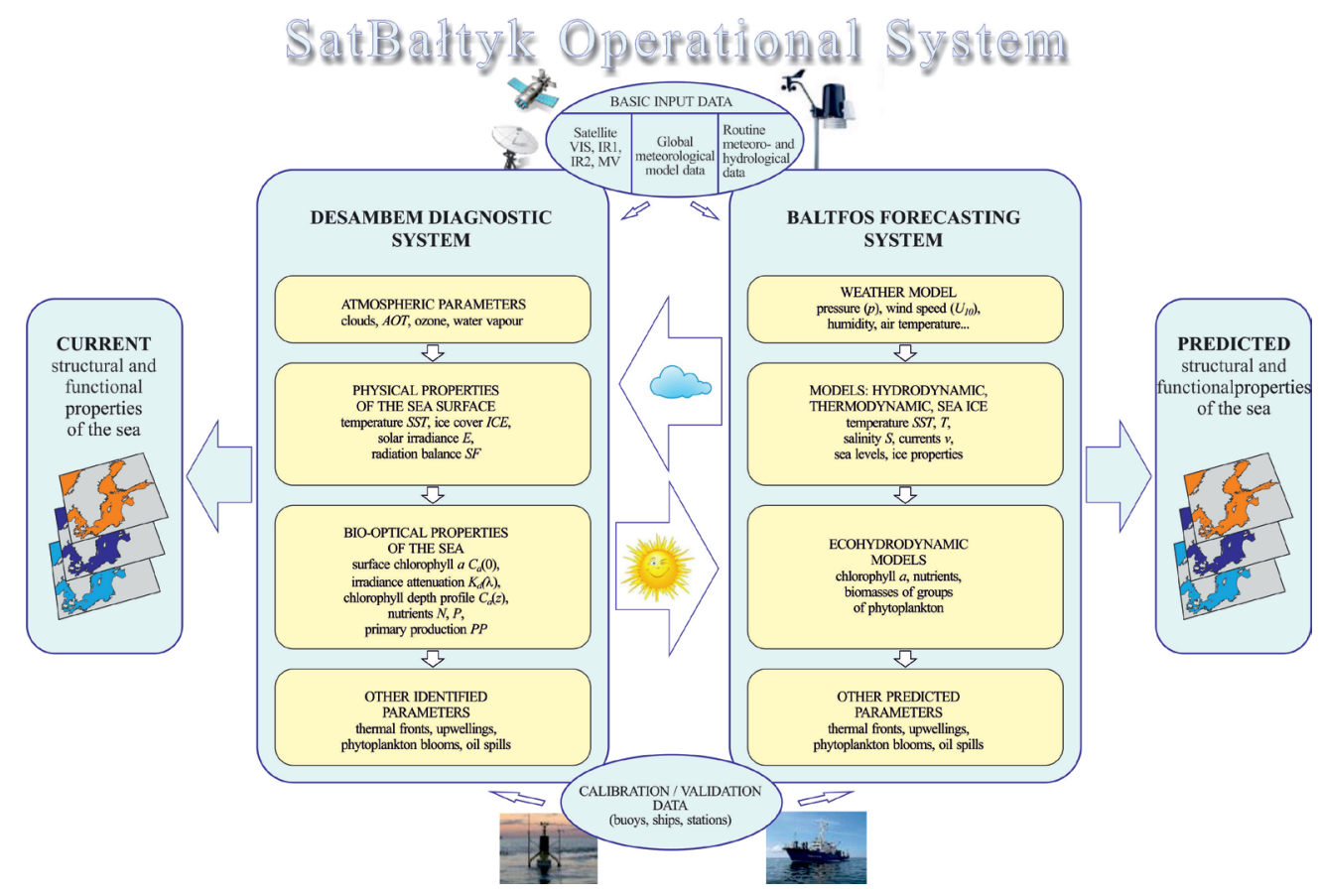

Fig. 1. Simplified general block of the Operational System SatBałtyk

radiometers and/or hydrometeorological data supplied by common routine services.

These two cooperating data processing subsystems are complementary within the framework of the SatBałtyk Operational System. So, for example, if direct remote sensing of the sea is not possible because the sky is overcast, especially if the sea surface temperature (SST) and the surface chlorophyll $a$ concentration $C_{a}(0)$ cannot be retrieved, the values of these data in the DESAMBEM subsystem serving to determine various current values of marine ecosystem parameters based on SST and $C_{a}(0)$ data are based on forecasts made by the BALTFOS subsystem (see the horizontal arrows from right to left between the subsystems in Fig. 1). On the other hand, the forecast values of parameters determined by the component models of the BALTFOS subsystem can be rectified by the assimilation of the actual values of these parameters determined by the DESAMBEM algorithm (see the horizontal arrows from left to right between the subsystems in Fig. 1).

\section{THE GENERAL SCHEME AND SELECTED RESULTS OF THE SATBAŁTYK OPERATIONAL SYSTEM FUNCTIONING}

The SatBałtyk Operational System (SatBałtyk OS) is a complex set of operational measurement instruments, mathematical models and procedures enabling the routine monitoring of different characteristics of the Baltic Sea environment as well as their presentation (mostly via the Internet) in the form of maps and tables, as well as severalday forecasts. The instrumentation used by SatBałtyk OS comprises receivers of data recorded by selected satellites, sets of measurements from marine and meteorological sondes, loggers, converters and transmitters of the data from these sondes, as well as laboratory analytical apparatus and a network of computer servers with installed databases, the relevant mathematical models and algorithms, to be used in accordance with stipulated procedures. Figure 2 illustrates the main components of the SatBałtyk operational system and of how it is ultimately expected to function.

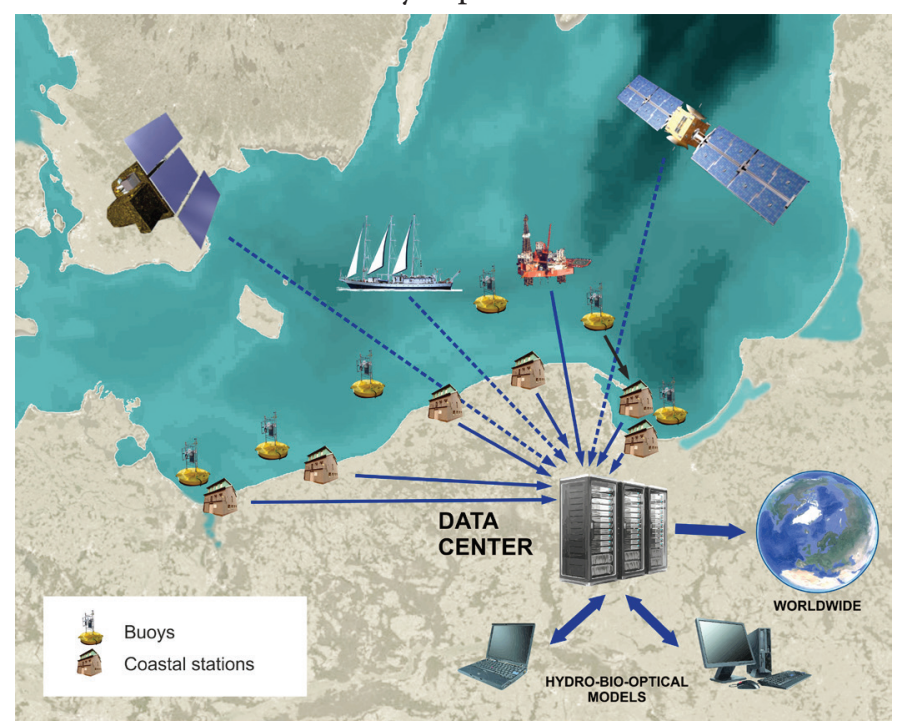

Fig. 2. Main components of the Operational System SatBattyk

The system utilizes data systematically recorded by environmental satellites and also special-purpose ones such as TIROS N/NOAA, MSG (currently Meteosat 9), EOS/AQUA and Sentinel -1, 2, 3 (in the future) regularly passing over the Baltic, and various in situ data measured on buoys and ships, shore stations and analyzed in laboratories belonging to Institutes from the Consortium SatBałtyk. 


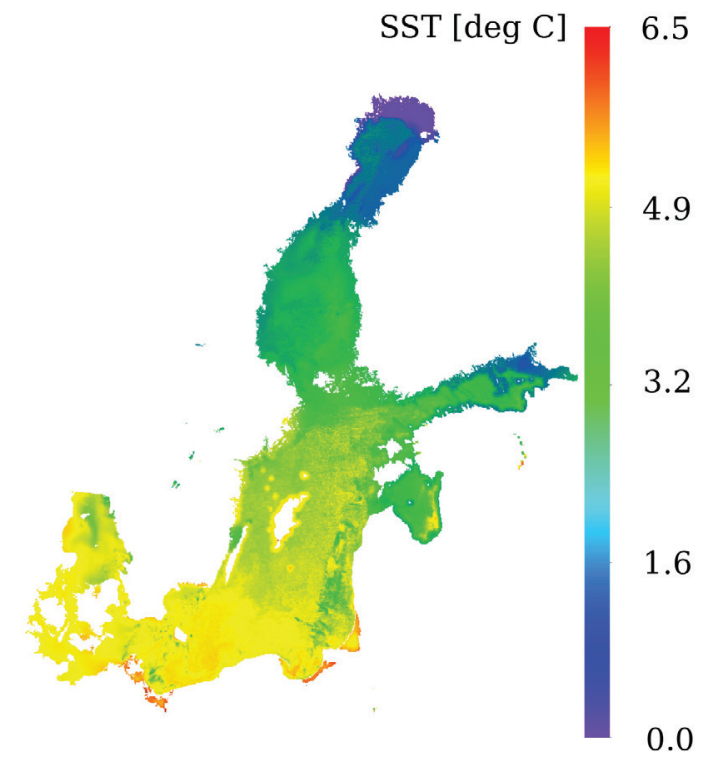

Fig. 3. Sea surface temperature (SST) of the Baltic Sea constructed on the basis of satellite data and completed by the model (17 03 2015)

As we have already stated, in the case of the Baltic, frequent cloudiness partially or entirely precludes the use of satellite sensors for recording radiation in the visible and thermal infra-red bands for diagnosing various parameters of the marine environment. Because of this the applicability of the DESAMBEM algorithms were expanded by linking them up with the set of algorithms from the BALTFOS Forecasting System. The latter are based on prognostic models and procedures for their adjustment by the assimilation of space born and other data and other data obtained using the diagnostic subalgorithms of the DESAMBEM (see Fig. 1). Presented in Fig. 3 map of the surface temperature SST of whole area of the Baltic Sea is constructed on the basis of satellite data and supplemented by the results of modelling.

The next example of the maps provided by the system, is phytoplankton assimilation number, characterizing the condition of phytoplankton, in particular its potential photosynthetic abilities.

Fig. 4 represents maximum possible rate of photosynthesis in waters for a fixed amount of nutrients in those waters and a particular sea water temperature expressed in numbers of atoms or moles of carbon assimilated in unit time by phytoplankton of unit chlorophyll content. Such maximum rates of photosynthesis are usually recorded at intermediate (photosynthetically optimal) depths, at which irradiance levels are still sufficiently high not to limit the rate of light reactions, yet not so high that destructive photoinhibition of the photosynthetic apparatus comes into play. In the Baltic such optimal conditions usually (in ca $66 \%$ of cases) prevail at depths from 1 to $5 \mathrm{~m} \mathrm{[29].}$

List of the various characteristics of the Baltic Sea environment, provided by SatBałtyk OS is constantly expanding and includes, for example: fluxes and budgets of radiant energy reaching the various regions of the Baltic and the amount of energy driving the Baltic ecosystem including the inflow and characteristics of radiant energy
PAR (photosynthetically ctive radiation $(\sim 400-700 \mathrm{~nm}))$ and UV (ultraviolet radiation), temperature distributions, the occurrence of upwelling events, the dynamic state of the sea surface, salinity of surface waters, the speed and direction of surface currents, upwelling events, water transparency indices and other optical properties of the sea, surface ice cover, the concentrations of chlorophyll and other phytoplankton pigments, blooms of toxic algae, the appearance of patches of pollutants such as oil slicks, characteristics of the primary production of organic matter and the release of oxygen into the water during photosynthesis, the humidity and ozone content in the atmosphere over the Baltic.

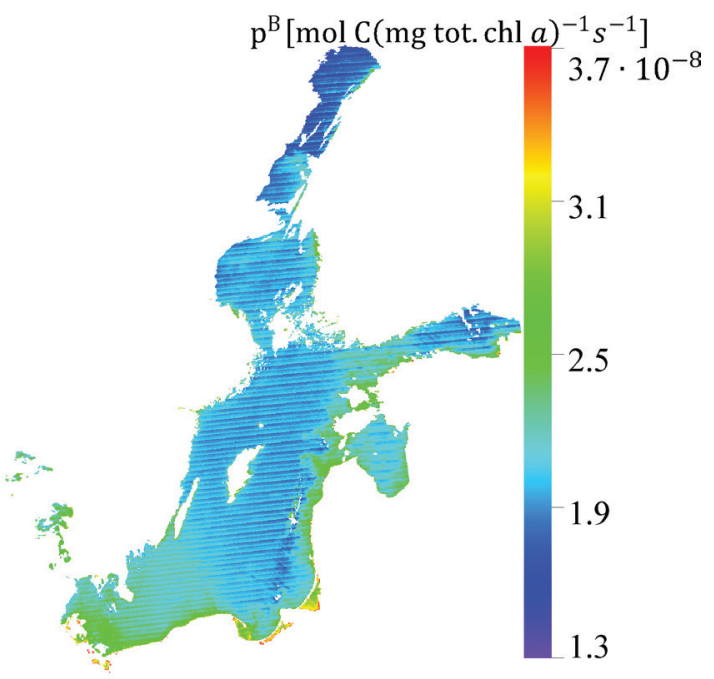

Fig. 4. Maximum rates of photosynthesis of the Baltic Sea constructed on the basis of satellite data (17 03 2015)

Integrated part of SatBałtyk system is a module called SatBałtyk-Brzegi, which allows to monitor two types of parameters of the coastal zone conditions and their prediction for two days in advance. Values of the first type of parameters are measured for one kilometer long sections of the coast for three pilot areas of a dune coast: Dziwnów Spit $(12 \mathrm{~km})$, Spit of Jamno and Bukowo Lakes $(10 \mathrm{~km})$ and Hel Peninsula $(6 \mathrm{~km})$, in perspective to cover the whole length of the Polish coast. Two days prediction consists of the following parameters: beach width inundation in percent; dry corridor of the beach; possibility of rip current occurrence in the nearshore. The second type of parameters shows consequences of the storm event and they are calculated after the process ends. The parameters are: volume of the erosion along the coastal profile: topography and bathymetry; volume of dune erosion at the one kilometer section along the coast; amount of inorganic suspended matter concentration. The calculation of parameters were done on a basis of hydromorphodynamic XBeach model which was adopted for pilot areas by [2] The model was also used to construct the Early Warning System of Storm Impact, developed by Szczecin University team in the framework of MICORE project [10]. Additionally two 
parameters: width inundation in percent; dry corridor of the beach, are calculated using statistical methods for the whole Polish coast. The values of parameters calculated in a framework of SatBałtyk project are crucial for research of costal processes and management. Predicted parameters are especially important for safety use of the coastal zone.

An important component of the SatBałtyk system is a systematic validation of the products provided by the service. In situ data, collected on every day basis at the platform and our buoy as well data from regularly organised cruises (usually 5 per year) are used to check accuracy of the products. Also a third-party data e.g. from ICES have been used to validate environmental parameters delivered by our system. The recent validation showed that accuracy of some of them are as follow: sea surface temperature - systematic error $-0.03^{\circ} \mathrm{C}$, statistical error $-0.91^{\circ} \mathrm{C}$; surface chlorophyll a concentration: - systematic error $-9 \%$, statistical error $-140 \%$; downwelling photosynthetically active radiationsystematic error $-0.11 \mathrm{Wm}^{-2}$, statistical error $-40 \mathrm{Wm}^{-2}$.

More information and characteristics of the Baltic Sea environment, can be find at the website www.satbaltyk.eu.

\section{CONCLUSIONS}

The article brings the summary of the results achieved during implementation of SatBałtyk project founded on the scientific outcomes from earlier, long-term studies of the Baltic environment by the Institutes forming the SatBałtyk Consortium. This system, based mainly on satellite data, enables making of maps of spatial distributions of many state parameters of this environment, as well as certain state parameters and optical properties of the atmosphere. The establishing the scientific foundations and methodology for employing remote sensing techniques to monitor the Baltic as an inland sea with a high biological productivity and yet under serious as a consequence of economic development is great Polish achievements. The final result of the project is the creation and setting in motion of the SatBałtyk Operational System for the comprehensive and effective monitoring of the current state of the marine environment, and also to a large degree for the forecasting of a whole range of natural phenomena taking place in Baltic waters and in the atmosphere above. The end of the work is schedule for December 31, 2015 after 72 months of implementation.

The magnitudes of ecosystem parameters determined using the set of SatBałtyk algorithms from NOAA, Meteosat, the MSG/SEVIRI and MODIS AQUA satellite data are compared with the magnitudes of the same parameters measured in situ. For these comparisons the relevant errors have been calculated. These errors are relatively small, typical of remote, spatial estimates. Such results can be regarded as satisfactory. Nevertheless, improvement of all the components of this complex algorithm will continue.

\section{ACKNOWLEDGEMENT}

The work was supported within the framework of the SatBałtyk project funded by the European Union through European Regional Development Fund, (contract No. POIG.01.01.02-22-011/09 entitled 'The Satellite Monitoring of the Baltic Sea Environment') and IO PAN statutory research.

\section{REFERENCES}

1. Antoine D., J. M. André, A. Morel: Oceanic primary production: 2. Estimation at global scale from satellite (Coastal Zone Color Scanner) chlorophyll, Global Biogeochemical Cycles 10 (1) (1996) 56-69.

2. Bugajny, N., Furmańczyk, K., Dudzińska-Nowak, J. i Paplińska-Swerpel, B., 2013. Modelling morphological changes of beach and dune induced by storm on the Southern Baltic coast using XBeach (case study: Dziwnow Spit). Journal of Coastal Research , 65, pp. 672-677.

3. Campbell J., D. Antoine, R. Armstrong, K. Arrigo, W. Balch, R. Barber, M. Behrenfeld, R. Bidigare, J. Bishop, M-E. W. Carr, Esaias, P. Falkowski, N. Hoepner, R. Iverson, D. Keifer, S. Lohrenz, J. Marra, A. Morel, J. Ryan, V. Vedemikov, K. Waters, C. Yentsch, J. Yoder: Comparison of algorithms for estimating ocean primary production from surface chlorophyll, temperature, and irradiance, Global Biogeochemical Cycles 16 (2002) 74-75.

4. Carr M-E., M. A. Friedrichs, M. Schmeltz, M. N. Aita, D. Antoine, K. R. Arrigo, I. Asanuma, O. Aumont, R. Barber, M. Behrenfeld, R. Bidigare, E. T. Buitenhuis, J. Campbell, A. Ciotti, H. Dierssen, M. Dowell, J. Dunne, W. Esaias, B. Gentili, W. Gregg, S. Groom, N. Hoepner, J. Ishizaka, T. Kameda, C. Le Quere, S. Lohrenz, J. Marra, F. Melin, K. Moore, A. Morel, T. E. Reddy, J. Ryan, M. Scardi, T. Smyth, K. Turpie, G. Tilstone, K. Waters, Y. Yamanaka: A comparison of global estimates of marine primary production from ocean color, Deep Sea Res. 53 (2006) 741-770.

5. Darecki M., D. Ficek, A. Krężel, M. Ostrowska, R. Majchrowski, S.B. Woźniak, K. Bradtke, J. Dera, B. Woźniak: Algorithms for the remote sensing of the Baltic ecosystem (DESAMBEM). Part 2: Empirical validation, Oceanologia 50(4) (2008) 509-538.

6. Darecki M., D. Stramski: An evaluation of MODIS and SeaWiFS bio-optical algorithms in the Baltic Sea, Remote Sens. Environ. 89 (3) (2004) 326-350.

7. Darecki M., S. Kaczmarek, J. Olszewski: SeaWiFS chlorophyll algorithms for the Southern Baltic, Int. J. Remote Sens. 26 (2) (2005) 247-260. 
8. Ficek D., B. Woźniak, R. Majchrowski, M. Ostrowska: Influence of nonphotosynthetic pigments on the measured quantum yield of photosynthesis, Oceanologia 42(2) (2000) 231-242.

9. Ficek D., R. Majchrowski, M. Ostrowska, S. Kaczmarek, B. Woźniak, J. Dera: Practical applications of the multicomponent marine photosynthesis model (MCM), Oceanologia 45(3) (2003) 395-423.

10. Furmańczyk, K., Bugajny, N., Dudzińska-Nowak, J., Andrzejewski, P., Trefenko, P., Giza, A,. Benedyczak, R. i Cieszyński, Ł., 2012. Projekt MICORE - podsumowanie zrealizowanych zadań. ZZOP w Polsce - stan obecny i perspektywy. Tom 4. Zagrożenia i systemy Ostrzegania, str. 77-86.

11. Krężel A.: Solar radiation at the Baltic Sea surface, Oceanologia 21 (1985) 5-32.

12. Majchrowski R., M. Ostrowska: Influence of photo- and chromatic acclimation on pigment composition in the sea, Oceanologia 42(2) (2000) 157-175.

13. Majchrowski R., M. Ostrowska: Modified relationships between the occurrence of photoprotecting carotenoids of phytoplankton and Potentially Destructive Radiation in the sea, Oceanologia 41(4) (1999) 589-599.

14. Ostrowska M., R. Majchrowski, D.N. Matorin, B. Woźniak: Variability of the specific fluorescence of chlorophyll in the ocean. Part 1. Theory of classical 'in situ' chlorophyll fluorometry, Oceanologia 42(2) (2000) 203-219.

15. Pelevin V. N., B. Woźniak, O. J. Koblentz-Mishke: Algorithm for estimating primary production in the sea from satellite sensing, Oceanologia 31 (1991) 57-72.

16. Platt T., S. Sathyendranath, A. Longhurst: Remotesensing of primary production in the ocean - promise and fulfilment, Philosophical Transactions of the Royal Society of London, Series B 348 (1995) 191-201.

17. Rozwadowska A.: Influence of aerosol vertical profile variability on retrievals of aerosol optical thickness from NOAA AVHRR measurements in the Baltic region Oceanologia 49(2) (2007) pp. 165-184.

18. Woźniak B., A. Krężel, J. Dera: Development of a satellite method for Baltic ecosystem monitoring (DESAMBEM) - an ongoing project in Poland, Oceanologia 46(3) (2004) 445-455.

19. Woźniak B., A. Krężel, M. Darecki, S.B. Woźniak, R. Majchrowski, M. Ostrowska, Ł. Kozłowski, D. Ficek, J. Olszewski, J. Dera: Algorithm for the remote sensing of the Baltic ecosystem (DESAMBEM). Part 1: Mathematical apparatus, Oceanologia 50(4) (2008) 451-508.
20. Woźniak B., J. Dera, D. Ficek, M. Ostrowska, R. Majchrowski: Dependence of the photosynthesis quantum yield in oceans on environmental factors, Oceanologia, 44(4) (2002) 439-459.

21. Woźniak B., J. Dera, D. Ficek, R. Majchrowski, M. Ostrowska, S. Kaczmarek: Modelling light and photosynthesis in the marine environment, Oceanologia 45(2) (2003) 171-245.

22. Woźniak B., J. Dera, D. Ficek, R. Majchrowski, S. Kaczmarek, M. Ostrowska, O.I. Koblentz-Mishke: Modelling the influence of acclimation on the absorption properties of marine phytoplankton, Oceanologia 41(2), (1999) 187-210.

23. Woźniak B., J. Dera, D. Ficek, R. Majchrowski, S. Kaczmarek, M. Ostrowska, O.I. Koblentz-Mishke: Model of the 'in vivo' spectral absorption of algal pigments. Part 1. Mathematical apparatus, Oceanologia 42(2) (2000) 177-190.

24. Woźniak B., J. Dera, R. Majchrowski, D. Ficek, O. I. Koblentz-Mishke, M. Darecki: 'IOPAS initial model' of marine primary production for remote sensing application, Oceanologia 39(4) (1997) 377-395.

25. Woźniak B., J. Dera, R. Majchrowski, D. Ficek, O.I. Koblentz-Mishke, M. Darecki: Statistical relationships between photosynthesis and abiotic conditions in the ocean - the IOPAS initial model for remote sensing application, Proc. SPIE 3222 (1997) 516-528.

26. Woźniak B., J. Dera: Light Absorption in Sea Water, Atmospheric and Oceanographic Sciences Library 33, Springer (2007) $454 \mathrm{pp}$.

27. Woźniak B., K. Bradtke, M. Darecki, J. Dera, J. DudzińskaNowak, L. Dzierzbicka-Głowacka, D. Ficek, K. Furmańczyk, M. Kowalewski, A. Krężel, R. Majchrowski, M. Ostrowska, M. Paszkuta, J. Stoń-Egiert, M. Stramska, T. Zapadka: SatBaltic - a Baltic environmental satellite remote sensing system- an ongoing project in Poland. Part 1: Assumptions, scope and operating range, Oceanologia 53(4) (2011) 897-924.

28. Woźniak B., K. Bradtke, M. Darecki, J. Dera, J. DudzińskaNowak, L. Dzierzbicka-Głowacka, D. Ficek, K. Furmańczyk, M. Kowalewski, A. Krężel, R. Majchrowski, M. Ostrowska, M. Paszkuta, J. Stoń-Egiert, M. Stramska, T. Zapadka: SatBaltic - a Baltic environmental satellite remote sensing system- an ongoing project in Poland. Part 2: Practical applicability and preliminary results, Oceanologia 53(4) (2011) 925-958.

29. Woźniak B., R. Hapter, J. Dera: Light curves of marine phytoplankton photosynthesis in the Baltic, Oceanologia 27 (1989) 61-78. 


\section{CONTACT WITH THE AUTHORS}

Mirosława Ostrowska

Institute of Oceanology Polish Academy of Sciences

Powstańców Warszawy 55, 81-712 Sopot

e-mail: ostra@iopan.gda.pl

\section{Mirosław Darecki}

Institute of Oceanology Polish Academy of Sciences Powstańców Warszawy 55, 81-712 Sopot

e-mail: darecki@iopan.gda.pl

\section{Adam Krężel}

University of Gdańsk, Institute of Oceanography Marszałka Piłsudskiego 46, 81-378 Gdynia e-mail: oceak@ug.edu.pl

\section{Dariusz Ficek}

Pomeranian University in Słupsk Bohaterów Westerplatte 64, 76-200 Słupsk e-mail: ficek@apsl.edu.pl

\section{Kazimierz Furmańczyk}

University of Szczecin Mickiewicza 16, 70-383 Szczecin e-mail: kaz@univ.szczecin.pl

\section{Poland}

